\title{
Die rol van die ouerhuis in die intergenerasionele geloofsvorming van die jeug in belang van'n geïntegreerde jeugbediening
}

\begin{tabular}{|c|c|}
\hline \multicolumn{2}{|c|}{$\begin{array}{l}\text { Authors: } \\
\text { Johan C. Avenant }{ }^{1} \text { (D) } \\
\text { Malan Nel }{ }^{1} \text { (D) } \\
\text { Joyce C. Jordaan }{ }^{2} \text { (D) }\end{array}$} \\
\hline \multicolumn{2}{|c|}{$\begin{array}{l}\text { Affiliations: } \\
{ }^{1} \text { Department of Practical } \\
\text { Theology, Faculty of Theology } \\
\text { and Religion, University of } \\
\text { Pretoria, Pretoria, } \\
\text { South Africa }\end{array}$} \\
\hline \multicolumn{2}{|c|}{$\begin{array}{l}{ }^{2} \text { Department of Statistics, } \\
\text { Faculty of Natural and } \\
\text { Agricultural Sciences, } \\
\text { University of Pretoria, } \\
\text { Pretoria, South Africa }\end{array}$} \\
\hline \multicolumn{2}{|c|}{$\begin{array}{l}\text { Corresponding author: } \\
\text { Johan Avenant, } \\
\text { johan@gesed.co.za }\end{array}$} \\
\hline \multicolumn{2}{|c|}{$\begin{array}{l}\text { Dates: } \\
\text { Received: } 26 \text { Mar. } 2021 \\
\text { Accepted: } 05 \text { May } 2021 \\
\text { Published: } 18 \text { Aug. } 2021\end{array}$} \\
\hline \multicolumn{2}{|c|}{$\begin{array}{l}\text { How to cite this article: } \\
\text { Avenant, J.C., Nel, M. \& } \\
\text { Jordaan, J.C., 2021, } \\
\text { 'Die rol van die ouerhuis } \\
\text { in die intergenerasionele } \\
\text { geloofsvorming van die jeug in } \\
\text { belang van 'n geïntegreerde } \\
\text { jeugbediening', Verbum } \\
\text { et Ecclesia 42(1), a2250. } \\
\text { https://doi.org/10.4102/ } \\
\text { ve.v42i1.2250 }\end{array}$} \\
\hline \multicolumn{2}{|c|}{$\begin{array}{l}\text { Copyright: } \\
\text { (C) 2021. The Authors. } \\
\text { Licensee: AOSIS. This wor } \\
\text { is licensed under the } \\
\text { Creative Commons } \\
\text { Attribution License. }\end{array}$} \\
\hline \multicolumn{2}{|l|}{ Read online: } \\
\hline 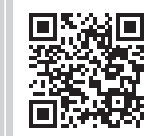 & $\begin{array}{l}\text { Scan this QR } \\
\text { code with your } \\
\text { smart phone or } \\
\text { mobile device } \\
\text { to read online. }\end{array}$ \\
\hline
\end{tabular}

The role of the parental home in the intergenerational faith formation of the youth for the sake of an integrated youth ministry. This article deals with the following question: What is the role of parents in the intergenerational faith formation of the youth for the sake of an integrated youth ministry? Several studies nationally and internationally have convincingly pointed out that parents have the biggest influence on their children's faith formation. However, parents are currently still not sufficiently inclusively involved or supported in youth ministry. Osmer's fourfold reflective equilibrium model forms the frame for how this article is structured. Nel's theory of inclusive youth ministry is used as a theological framework from which the role of parents in intergenerational faith formation is investigated. The empirical research (quantitative, as well qualitative) was conducted among 175 parents and 10 ministers coming from 29 congregations in the Noordelike, Oostelike, Hoëveld- and Goudland synods of the Dutch Reformed Church. These congregations all have a family and/or intergenerational focus in their (youth) ministry. The research has shown that youth ministry cannot by means of programmes, structures and even relationships in any way replace the important role played by parents in the lives of their children, regardless of what happens in the youth ministry. When the parental home and youth ministries do not act as partners in the faith formation process, it does not only lead to weak faith, but also to a lack of commitment, unsustainability and ultimately alienation. Youth ministries can therefore not function effectively without an integrated ministry, which includes the parental home. With all the challenges threatening their capacity, the parental home can also not function effectively as faith mediators without an inclusive youth ministry. The research thus clearly indicates that Nel's theory of inclusive youth ministry, is not only noteworthy, but it is also in the long term, necessary to work towards the congregation's eschatalogical sustainability.

Intradisciplinary and/or interdisciplinary implications: Youth ministries do not involve parents as the core part of their ministry. When youth ministries integrate parents into their ministry, children will be better guided in their faith formation. This adjustment calls for a paradigm shift in the focus of traditional youth ministry. Intergenerational faith formation in this study was approached within the framework of Practical Theology, Congregational Development and Youth Ministry.

Keywords: intergenerational faith formation; faith formation; inclusive youth ministry; integrated youth ministry; parental home; faith forming process; Didache; faith identity.

\section{Inleiding}

Die rol van die ouerhuis in geloofsvorming is die afgelope paar dekades 'n belangrike besprekingspunt in jeugbediening. Verskeie studies nasionaal en internasionaal het oortuigend uitgewys dat ouers die grootste invloed op hul kinders se geloofsvorming het (Avenant \& Hoffman 2015:64; Holmen 2010:32; Smith \& Denton 2005:56). Tog word die ouerhuis steeds nie genoegsaam inklusief in jeugbediening betrek of ondersteun nie. Dit laat die vraag ontstaan: hoekom sluit jeugbedienings en gemeentes steeds nie ouers by hulle bediening aan kinders, adolessente en jong volwassenes in nie? Hierdie saak vra om hierdie rede opnuut besinning en dringende aandag.

Tydens die PhD-navorsing wat hierdie artikel voorafgegaan het, is daar ondersoek ingestel na die rol van intergenerasionele geloofsvorming in huis-gefokusde en gemeente-ondersteunde jeugbediening. Die navorsing het spesifiek gefokus op die rol wat die ouerhuis in intergenerasionele geloofsvorming in jeugbediening vervul. Die navorsing het verder gefokus op 
hoe jeugbediening met teologies verantwoorde aanpassings op hierdie uitdaging in jeugbediening kan reageer.

\section{Probleemstelling}

Die navorsingsvraag van hierdie artikel kan soos volg geformuleer word: Wat is die rol van die ouerhuis in die intergenerasionele geloofsvorming van die jeug, in belang van 'n geïntegreerde jeugbediening?

Binne die empiriese benadering is ' $n$ kombinasie van eksplorerende en toetsende navorsing gekies. Die metodologie wat in hierdie artikel gevolg word, sluit aan by Osmer (2008:4) se reflektiewe ewewigsmodel. Ter wille van 'n geheeloorsig van die artikel, word die probleemstelling soos volg hanteer: Die probleem word eers omlyn (deskriptief empiriese taak), waarna kortliks moontlike redes vir die probleem uitgewys word uit die literatuur en empiriese navorsing (interpretatiewe taak). Daarna word gekyk na wat 'n geïntegreerde jeugbediening behels en hoe intergenerasionele geloofsvorming bydra tot die vorming van die jeug se geloof. Daar word ook spesifiek gekyk na die rol van die ouerhuis binne intergenerasionele geloofsvorming (normatiewe taak). In die laaste deel van die artikel, word empiriese data in verband met die ouerhuis se rol in geloofsvorming in belang van 'n geïntegreerde bediening ingespan, om te help bepaal hoe ouers deel gemaak kan word van jeugbediening (pragmatiese taak). Die artikel word afgesluit met enkele gevolgtrekkings.

\section{Omlyning van die probleemstelling}

Die feit dat jeugbedienings, ten spyte van oortuigende navorsingsresultate dat ouers die grootste invloed op hulle kinders se geloofsvorming uitoefen, steeds nie ouers 'n kerndeel van hulle bediening maak nie, is in hierdie studie bevestig. In die identifiseringsproses van respondente vir die empiriese navorsing van die studie, is slegs 35 uit die 436 gemeentes in die afgebakende gebied waarin hierdie studie gedoen is, geïdentifiseer met 'n gesins- en/of, familie- en/of 'n intergenerasionele fokus in hulle (jeug-) bediening. Van die 35 geïdentifiseerde gemeentes het net 29 uiteindelik deelgeneem. Dit was ook opmerklik dat $75 \%$ van die respondente (ouers) wat deelgeneem het, aangedui het dat die jeug in hulle gemeentes hoofsaaklik afsonderlik, maar soms saam met volwassenes, bedien word. 'n Volledige beskrywing van die navorsingsproses volg later.

\section{Redes waarom ouers nie 'n kerndeel van jeugbediening uitmaak nie}

Daar is sekerlik geen enkelvoudige rede hoekom ouers nie 'n kerndeel van jeugbediening uitmaak nie. Die literatuur en navorsing het egter wel belanrike sake uitgewys:

Deur die hele Christelike geskiedenis heen voor die Industriële Revolusie, was die ouerhuis die kern waarom heen die bediening gedraai het (Allen \& Ross 2012:17). Corbett en Johnson (1972) verwoord dit soos volg:
The term 'youth work', or 'youth ministry' came into being after the Industrial Revolution of the nineteenth century. Before this the congregation was a family organization with very few activities for specific age groups. (bl. 3)

'n Verskeidenheid redes het veroorsaak dat die jeug meer afsonderlik van volwassenes bedien is en dat ouers mettertyd uit die (jeug-) bediening geskuif is. Die redes hou veral verband met wat Westerhoff (2000:191) noem, die opkoms van die nuwe verstaan van kinderontwikkeling en opvoedkunde en die gepaardgaande skoolsisteem van onderrig wat daarop gevolg het. Hy (Westerhoff 2000:318-350) wys ook op die rol wat die erodering van die ekologie van verhoudings gespeel het en steeds speel. Dit sluit 'n veranderde konteks, die samestelling van gesinne, enkelouerskap, werksdruk en nog baie meer in. Ouers en gesinne lyk en funksioneer volgens Roberto (2016:27) dramaties anders vandag as in vorige generasies. Hierdie veranderde konteks het gepaardgegaan met dit wat Neufeld (2002:194) die kulturele paradigma van postmodernisme noem. Dit word gekenmerk deur sekularisme, pluralisme, relativisme, eksistensialisme, individualisme en materialisme. Dit alles het die funksionering van die samelewing in die algemeen, maar ook die funksionering van gesinne en die kerk radikaal beïnvloed, en bygedra tot die skuiwe wat binne kerke en gemeentes ten opsigte van geloofsvorming plaasgevind het.

Op die vraag in die kwalitatiewe navorsing, is aan respondente (leraars) gevra wat, na hulle oordeel, die rede is hoekom gemeentes steeds nie ouers 'n sentrale deel maak van hulle jeugbediening nie. Daar is redelike eenstemmigheid oor drie hoofredes hiervoor: eerstens die kapasiteit van ouers, wat om verskeie redes, hulle verhinder om betrokke te wees; tweedens het negatiewe ervarings van en die persepsies oor ouers by leraars en jeugleiers gemaak dat hulle nie betrek word nie; en derdens het die rol wat tradisie en die generasiegaping speel, dit baie moeilik gemaak om ouers betrokke te kry en betrokke te hou. Dit is ook opmerklik dat die kwantitatiewe data iets van die gebrek aan kapasiteit by ouers bevestig het. Respondente (ouers) het net een saak as ' $n$ beduidende uitdaging vir geloofsvorming in die huis uitgewys: meer as tweederdes (69\%), dui aan dat hulle grootste uitdaging is om tyd as gesin saam te vind. Respondente (ouers) beleef egter nie die generasiegaping as ' $n$ enigsins beduidende faktor, wat intergenerasionele interaksie in hulle gemeentes verhinder nie. Minder as 'n derde van die ouers (31\%) het dit as 'n uitdaging aangedui.

\section{Inklusiewe jeugbediening as 'n lens op ouers se rol in 'n geïntegreerde jeugbediening}

Nel (2018:213-242; cf. ook Nel 2001a:77-96) se teorie van inklusiewe jeugbediening, vorm die groter teologiese raamwerk van waaruit daar in hierdie studie na die rol van die ouerhuis in intergenerasionele geloofsvorming gekyk word. Die kern van die teorie is dat jeugbediening en die jeug 'n integrale deel van 'n gemeente en 'n 
omvattende gemeentebediening vorm (Nel 2018:215; cf. ook 2001b:4). Nel (2018) beskryf sy benadering tot jeugbediening soos volg:

$[I] \mathrm{n}$ my understanding, Youth Ministry is inclusive, comprehensive, and that includes (or at least stands in direct relationship to) catechesis and family ministry. (bl. 22)

In hierdie beskrywing kan reeds gesien word dat die ouerhuis 'n deurslaggewende rol in dié teorie vervul. Hierdie benadering wil ekklesiologie en jeugbediening nader aan mekaar bring, en jeugbediening help om op 'n meer teologiese basis te funksioneer. Dit wil ook iets van die gemeenskaplike karakter van ekklesiologie in jeugbediening terugbring. Nel (2018) verwoord dit soos volg:

The basic theory maintained here is that the children of the people of the covenant, people who live in a relationship with God and with one another, are an integral part of the community of faith, of the congregation in its many Gestalts. (bl. 77)

God se totale betrokkenheid by, met en deur die mens, word deur Bosch (1979:245 en 1991:389 e.v.) se alombekende woorde, missio Dei, beskryf. Dit verwys na God se koms na die wêreld. God kom op baie maniere na die wêreld en na sy skepping. God kom primêr deur sy Woord en Gees na die wêreld, maar Hy sluit mense (ouers) in by hierdie koms. Om betrokke te wees by jeugbediening, is niks minder nie as 'n deelname aan God se koms en 'n deelname aan wat Hy besig is om te doen nie. Al die mense se pogings om 'bediening' te verstaan, is volgens Nel (2001a:80) pogings om God se koms deur sy Gees en Woord en deur die diens van mense te verwoord.

Tradisioneel word hierdie koms van God deur sy Woord en deur die diens van mense, volgens Nel (2018:221; cf. ook 2001b:6) deur sewe bedieningsmodi beskryf. Nel voeg 'n agtste modus by, naamlik Organisasie/Leierskap/ Administrasie (Kubernetiek). Die ander sewe bedieninge is Verkondiging (Kerugma), Erediens of Aanbidding (Leitourgia), Pastorale sorg (Paraklese), Onderrig (Didache), Gemeenskap (Koinonia), Diens (Diakonia) en Getuienis (Marturia). In al agt bedieninge gaan dit oor ' $n$ drie-dimensionele diens - diens aan God, diens aan mekaar en diens aan die wêreld. Hierdie bedieninge fasiliteer volgens $\mathrm{Nel}$ en Van der Westhuizen (2015:63-83) nie net God se koms na die wêreld nie, maar ook 'n identiteitsontdekking en -ontwikkeling. Indien hierdie agt bedieninge die kernbedieninge is waaroor dit in die gemeente behoort te gaan, dan wil inklusiewe jeug- en gesinsbediening seker maak dat dit ook die kern is waaroor dit in jeugbediening en in gesinsbediening gaan. Deelname aan hierdie bedieninge help dus kinders, adolessente en jong volwassenes in hulle identiteitsontdekking en -ontwikkeling. Jeugbediening se taak is tweevoudig: Eerstens, om elke bediening te sensiteer om dit vir die jeug en vir gesinne relevant te maak. Tweedens, om die jeug en gesinne se plek in die gemeente te herontdek en te herdefinieer. Hier kan moontlik 'n derde taak bygevoeg word, naamlik om gesinne te bemagtig, aan te moedig en te ondersteun om deel te neem aan die bedieninge en op te tree as fasiliteerders van hulle kinders se identiteitsontdekking en -ontwikkeling in hierdie proses.
Jeugbediening en gesinsbediening is om hierdie rede nie 'n ander, of bykomende bediening, of modus van God se koms na die jeug (of gesinne) toe nie (Nel \& Van der Westhuizen 2015:74; cf. ook Nel 1994:10; 2001b:82-83). Daar is daarom geen enkele teologiese rede waarom dit wat vir volwassenes en die gemeente geld, nie ook vir kinders, adolessente en jong volwassenes (en hulle gesinne) geld nie (Nel 2001a:83). Wat dus in 'n gemeente se bediening met die ouers gebeur, behoort saam met hulle kinders te gebeur. Dit gaan in jeugbediening en gesinsbediening nie om 'n ekstra plek vir nog 'n bediening te vind nie, maar om vir die jeug en gesinne plek te vind, binne die ruimte en tussen die mense op wie die bediening gerig is - die mense na wie God deur die bedieninge kom. Elke bediening het relevansie vir die jeug en hulle gesinne en behoort dus so ingerig te word.

\section{'n Teologiese werksformule}

Jeugbediening is volgens Nel (2018:242; cf. Nel 2001a:88) die bemiddeling van die koms van God deur sy Woord en diens van mense (hier kan spesifiek ouers ingevoeg word), deur alle bedieningsmodi op 'n gedifferensieerd toegespitste wyse aan en deur die jeug, as 'n wesenlike deel van die gemeente.

Bemiddeling veronderstel persone wat reeds deelneem aan God se koms deur sy Woord en Gees, en deel is van en ook deelneem aan die werksaamhede van die gemeente (jeugbediening). Daar word dus veronderstel dat ouers en ander volwassenes in die gemeente die persone is waarna hierdie werksformule verwys. Om dié rede kan jeugbediening nie effektief plaasvind sonder dat die ouerhuis inklusief deel hiervan uitmaak nie.

\section{Wanneer inklusiwiteit ontbreek, vind vervreemding plaas}

Die afwesigheid van 'n inklusiewe benadering tot jeugbediening, waar die jeug aanvaar word as integrale deel van die gemeente, en waar die jeugbediening integraal deel is van die totale bediening van die gemeente, het volgens Brierley (1993:89-168) dikwels tot 'n negatiewe evaluering van die gemeente deur die jeug gelei. Hierdie gedagte is net so waar vir gesinne ook. Wanneer gesinne nie deel voel of beleef dat hulle deel is van die totale bediening van die gemeente nie, dan evalueer hulle nie net die gemeente negatief nie, maar beïnvloed hulle hul kinders ook negatief. In so 'n geval gaan soek die jeug (en gesinne) 'n plek elders wat aan hulle geestelike behoeftes voldoen, en hulle gaan daar aanbid of eredienste bywoon.

\section{Intergenerasionele geloofsvorming}

Om die rol van die ouerhuis in die intergenerasionele geloofsvormingsproses van die jeug binne die raamwerk van 'n geïntegreerde jeugbediening te verstaan, is dit belangrik om duidelikheid te kry oor wat intergenerasionele geloofsvorming behels.

Wanneer daar na intergenerasionele geloofsvorming verwys word, gaan dit oor die interaksie tussen verskillende generasies wat deel vorm van die geloofsvormingsproses. Wanneer 
intergenerasionaliteit spesifiek op geloofsvorming van toepassing gemaak word, is White (1988) se definisie van intergenerasionele geloofsvorming alreeds vir jare die rigtinggewende riglyn:

When two or more different age groups of people in a religious community together learning/growing/living in faith through in-common experiences, parallel learning, contributiveoccasions, and interactive sharing. (bl. 18)

Intergenerasionele geloofsvorming gaan dus oor meer as net die bymekaarwees of bymekaarbring van verskillende generasies. Dit gaan oor beplande interaksie tussen persone uit verskillende generasies, met die oog op geloofsvorming. Daar word in hierdie artikel gefokus op die rol van die ouerhuis, as eerste linie van rolspelers betrokke by intergenerasionele geloofsvorming. Intergenerasionele geloofsvorming behels egter baie meer as net die ouerhuis.

\section{Teologiese perspektiewe op intergenerasionele geloofsvorming}

Geloofsvorming het uit die onderrigtaak van die kerk ontwikkel, daarom geld dieselfde teologiese perspektiewe wat vir onderrig (Didache) geld, net so vir intergenerasionele geloofsvorming. Geloof gaan nie net oor iets abstraks wat geleer moet word en dan is dit klaar nie. Dit behels volgens Dingemans (1986:87) 'n kognitiewe, affektiewe en houdingsleer. Teologies gesproke, is onderrig vir Dingemans (1986:154-168) om Christus te volg, of om op sy weg te leer loop. Dit gaan vir hom in die onderrigproses dus om leerling te word en leerling te wees - dit gaan hier oor navolging (akolouthein).

In die Bybel word die lewe van God se mense (verbondsmense) volgens Nel (2018:159; cf. ook Nel 2001b:137) dikwels met 'n 'weg', of pad (hoe 'n mens moet lewe) voorgestel (Spreuke $3: 1-6 ; 22: 6)$. Die pad of lewe het 'n bestemming. Op hierdie reis van gelowiges saam met God, vind ontwikkeling en groei plaas. Of iemand binne die verbondskring gebore en grootword, en of hulle later deur God daarin geroep word hierdie pad moet geleer word. Wat geleer moet word, is wat die pad saam met God behels; hoe daar op hierdie pad geloop (geleef) moet word, en hoe die nuwe identiteit gevorm word met die transformasie wat daarmee gepaardgaan. Dingemans (1986) lê klem op die omvattendheid van hierdie leerproses (pad) en hy veronderstel die insluiting van die ouershuis wanneer hy van geloofsopvoeding praat:

Geloofsopvoeding is geen apart hoofstuk binnen de algemene opvoeding: het is er een essentieel en alles-doordringend deel van. Opvoeding is: kinderen leiden op die weg van het leven en dat is - naar oud-israëltisch besef - de weg van de Heer. (bl. 159)

Die pad wat God se mense stap, is 'n geloofspad. Geloof gaan altyd van God uit - God neem inisiatief en Hy skenk geloof (cf. Nel 2001a:148). Hierdie geskenkte geloofsinsig moet ontdek word en dit moet groei. Dit is hier waar onderrig (Didache) of geloofsvorming inpas. God is self die een wat sy mense op hierdie pad wil leer. In die Ou Testament word, volgens Firet (1977:91), geleer dat die Torah God se 'wegwysende stem' op hierdie pad is. In die Nuwe Testament roep en onderrig Jesus self sy dissipels. In hierdie leer- of vormingsproses sluit God, volgens Firet (1977:71-78), ook mense (ouers en alle ander gelowiges) in, as medereisigers, om nuwe reisigers (kinders en volwassenes) saam te nooi en op hierdie weg in te lyf, of te inisieer en te begelei. Dit is hier waar intergenerasionele geloofsvorming as 'n onontbeerlike bousteen beskou word.

Dingemans (1986:116) noem die menslike betrokkenheid by die geloofsvormingsproses, 'geloofsbemiddeling'. Hierdie bemiddelaars - veral die ouerhuis - wat God insluit in die kommunikasieproses, is in hierdie artikel van kardinale belang. Jeugbediening kan nie hierdie bemiddelingsrol vervul sonder ouers wat daagliks hulle geloof voor en saam met hulle kinders uitleef nie. Die ouerhuis is die eerste plek van bemiddeling van God se koms en betrokkenheid in kinders se lewens. God gebruik ouers, maar ook ander gelowiges, om kinders en nuwe reisigers op sy pad deur Didache te begelei. Om in staat te wees om die bestemming wat God vir sy mense in die oog het, te bereik, is volgens Firet (1986:53), channukkâ - inisiasie, opleiding, en /oordrag van toewyding - nodig. Firet (1982:71-72) soos aangehaal deur Nel (2009) beskryf hierdie inisiasieproses soos volg:

The 'transfer of dedication' consists especially in the initiation of the child into the story of Yahweh and his people: it implicates him personally so that it becomes his story. The child is initiated into the story with a view of where he has to go. The 'way' did not begin when he was born: it started with the Exodus. He was there when it happened. The didaché is not primarily an explanation of history, or of the words and works of Yahweh. It is first of all the act of implicating the young Israelite in the story of salvation. He learns to say and to experience we - the we of the covenant. (bl. 6; cf. ook 2001a:139)

Die ouerhuis is by uitstek die plek waar kinders leer om 'ons' te sê - ons wat deel is van God se mense - die liggaam van Christus (Nel 2009:6). Voordat 'n kind enigsins besef dat hulle deel is van enige groep, beleef hulle dat hul deel is van hul eie familie, wat deel is van God se familie. Dit is ouers wat die eerste geloofstories aan hulle kinders vertel.

In hierdie lig beskryf Firet (1986:50-68; 1982:71-76 ; cf. ook Nel 2009:101-102 en 2018:41-42, 160,) die Didache van die Ou Testament as 'n uitnodiging na inisiasie in, en begeleiding en onderskeiding op hierdie weg. 'Hierdie weg', verwys volgens hom in die Nuwe Testament na 'n omvattende lewe van dissipelskap. Die term dissipelskap, dui volgens Nel (1994:88-89) op ten minste twee dimensies, naamlik navolging (Jesus se Heer-skap op die pad word al meer deurslaggewend) en leerling wees (gehoorsaamheid aan die Woord en wil van die Here). Daar kan ook 'n derde dimensie van dissipelskap bygevoeg word, naamlik die styl waarin die leer of opleiding plaasvind. Hierdie styl het te doen met onderrig of leer wat plaasvind wanneer daar saam met iemand, wat al langer op die geloofspad is, aan die bediening van die Here deelgeneem word (Allen \& Ross 2012:102).

\section{Intergenerasionele geloofsvorming gebeur prosesmatig}

Geloofsvorming of onderrig vind nie net op'n gegewe moment of gedurende ' $n$ gegewe tyd, byvoorbeeld in die kinderjare, 
plaas en dan is dit afgehandel nie. Osmer (1996:163) dui aan dat inisiasie en begeleiding tydens die afrondingsfase van die kategumenaat van die vroeë kerk, liturgiese handelinge begin insluit het, wat simbolies die betrokkenheid van die Heilige Gees by die Christelike lewe vergestalt het. Hierdie liturgiese momente was volgens hom deel van 'n proses wat primêr kategeties was. Dit was 'n proses van formasie, waarin onderrig, aanbidding en geestelike begeleiding saamgewerk het om nuwe gewoontes in denke, gevoelens en praktyke by die persone wat geïnisieer is in die kerk, te help kweek. Dit is hierdie prosesstruktuur van die kategumenaat, wat Wepener (2014:157), op die voetspoor van Kreider (1999:21-22), laat formuleer het dat begeleiding op die geloofspad 'belief, behaviour' en 'belonging' stimuleer en beoog. Geloofsvorming is binne hierdie proses dus daarop gerig, om oor tyd heen geloof, gedrag en 'n ervaring van behoort te kweek. Wanneer ons aan intergenerasionele geloofsvorming dink, dan word juis hierdie prosesmatigheid van die ontwikkeling van geloof en groei opgeneem. Dit is binne die prosesmatige begeleiding dat langtermyn verhoudings en intergenerasionele interaksie 'n baie belangrike rol vervul. Die ouerhuis is die plek waar langtermynverhoudings reeds bestaan, en waar geloofsgewoontes en geloofspraktyke oor tyd heen aangeleer word, en ook gereeld beoefen word, of nie. Ouerhuise is om hierdie rede die ideale plek waar geloof, gedrag en 'n ervaring van behoort oor tyd heen gekweek behoort te word.

\section{Wat intergenerasionele geloofsvorming beoog}

Om te verstaan wat geloofsvorming beoog, help 'n definisie of omskrywing van geloofsvorming die beste: In jeugbediening gaan geloofsvorming oor die doelbewuste proses waardeur kinders, adolessente en jong volwassenes begelei word om hulle geloofsidentiteit te ontdek, te omarm en op dié wyse te groei in hulle verhouding met God. Intergenerasionele geloofsvorming verwys dan na al die intensionele prosesse, waar meer as een generasie betrokke is in die inlywing, begeleiding en onderskeiding van verbondsmense in en op ' $n$ dissipelskappad saam met God. Die ouerhuis is in hierdie verband ' $n$ onontbeerlike skakel in die begeleidings- en geloofsvormingsproses. Hierdie proses help verder mee en dra daartoe by dat ' $n$ omvattende verbondsverhouding (geloof) in individue ontwikkel. Dit dra verder by dat die Godgeskenkte geloofsinsigte groei en ontwikkel binne die begeleidingsproses, en deur deelname aan Christus se bediening (modi). Dié begeleiding en deelname het tot gevolg dat individue word wat hulle in Christus Jesus reeds is (nuwe identiteit in Christus). Dit verteenwoordig die hele transformasieproses op die geloofspad. Hierdie vorming en transformasie vind deurlopend, maar ook lewenslank in gelowiges se lewe plaas. Aspekte van die beskrywing van geloofsvorming, word deur verskillende navorsers beklemtoon, onder andere Avenant en Hoffman (2015:63), Bijlsma (1962:7), Firet (1982:172-173), Harris (1989:43-64), Nel (2001b:147-150), Prins (1995:24), Simpson (1999:23) en Wilhoit (2008:23).

Die vormingsproses het ten minste drie funksies in die lewe van die individue (kinders, adolessente en jong volwassenes, in hierdie artikel), wie se geloof gevorm word. Hierdie funksies speel 'n voortgaande rol soos wat individue se insig groei, en hulle bevatlikheid ontwikkel (NGK 2019:299-302).

Dit help eerstens met oriëntasie: waaraan verbind ek my en waar bevind ek my op die lewensreis, as deel van my geloofsfamilie? Dit het te doen met identiteit en identiteitsvinding. Oriëntasie behels volgens Westerhoff (1974:37-39) en White (1988:98) hoofsaaklik drie dinge: (i) Dit gaan oor die vermoë om jouself in die groter narratief van die gesin, groep of gemeenskap (gemeente) te plaas; (ii) Dit omlyn die waardes of basiese raamwerk, waardeur die individu die wêreld beoordeel; en (iii) Dit definieer die rolle, of wat in die algemeen van 'n individu verwag word, beide in die daaglikse roetine en in die verhoudings met ander.

In die tweede plek help dit met identifikasie - aan wie verbind ek my en wie is aan my verbonde? Dit het te doen met verhoudings - met God en medegelowiges. Dit behels volgens Nel (2001:110) modellering en die waarneming van rolmodelle. Dit kan ook beskryf word as vereenselwiging.

Derdens help dit om tot ' $n$ belydenis te kom - ek bely dat Jesus Christus my Here is en dat ek deel van die liggaam van Christus is. Dit het te doen met ' $n$ verbintenis - God se verbintenis aan my en my reaksie van oorgawe en verbintenis aan Hom en sy liggaam op aarde, en die gesamentlike navolging en deelname aan sy voortgesette bediening op aarde.

Oriëntasie, identifikasie en belydenis bewerk geloof (believe), gedragsverandering (behave) en 'n ervaring van behoort aan (belong). Dit is wat as oogmerk vir die kategumenaat beskryf is. Al drie funksies is van herhalende en voortgaande aard, op 'n lewenslange reis van dissipelskap. In al drie funksies van die vormingsproses, vervul mense - spesifiek ouers en ander volwassenes - 'n deurslaggewende rol. Hierdie rol is veral krities belangrik in die lewens van kinders, adolessente, jong volwassenes en volwassenes wat later hulle dissipelskapsreis begin, omdat dit die eerste fase van hulle geloofsreis verteenwoordig.

\section{Intergenerasionele solidariteit en momentum in kultuuroordrag}

Intergenerasionele interaksie speel'n onontbeerlike sosiologiese rol in die geloofsvormingsproses. Daar is in hierdie artikel nie ruimte om die rol van intergenerasionele dinamika en solidariteit volledig te bespreek nie, maar daar gaan wel enkele gedagtes hieroor gedeel word, waar dit van toepassing is op die gesin. Die huisgesin is waarskynlik die belangrikste plek binne 'n gemeente of gemeenskap waar geloofsosialisering plaasvind.

Bengston, Putney en Harris (2013) het na hulle longitudinale studie oor die oordrag van geloof van een generasie na die volgende, die belang van intergenerasionele interaksie in geloofsvorming soos volg opgesom:

In reviewing the thirty-five years of data we had collected from over 3500 family members we were struck how often we saw persistent patterns of religion (and sometimes non-religion) 
across generations. Something about religion seems to 'stick around' families over generations, more so than other characteristics such as political and social attitudes, values reflecting humanism and materialism, and psychological attributes such as self-esteem and depression. (bl. 138)

Bengston en sy kollegas se bogenoemde navorsing, lig spesifiek die rol van die ouerhuis in intergenerasionele geloofsvorming uit. Hulle (Bengston et al. 2013:193) stel 'n teorie of model voor, wat hulle 'intergenerational religious momentum' noem. In hierdie teorie wys hulle kontekstuele en godsdienstige faktore uit wat die geloofsmomentum verhoog of verhinder. In die kern van die teorie is die gesin se invloed. Ouers het volgens hierdie teorie die heel belangrikste invloed op geloofsvorming en die oordrag van 'n geloofstradisie. Die eerste saak van belang by ouers is hulle voorbeeld. Dit gaan hier oor wat ouers doen om 'n voorbeeld in geloofsgewoontes en -oortuigings te stel soos byvoorbeeld gereelde erediensbywoning, deelname aan kerklike aktiwiteite en die aanmoediging van geloofsvorming by die huis deur gebed, Bybellees en om Bybelstories te vertel. Die belangrikste saak in hierdie verband is die konsekwentheid tussen wat hulle sê en doen: 'walking the walk and not just talking the talk'. Die tweede saak handel oor die kwaliteit van die ouer-kindverhouding, wat hulle intergenerasionele solidariteit noem. Die data wys daarop dat die affektiewe of emosionele dimensie van die ouers se gedrag baie belangrik is in geloofsoordrag. Bengston et al. (2013) beskryf dit soos volg:

Parents who are warm and affirming are more likely to have children who follow them; parents who are cold or authoritarian, ambivalent or distracted, are less likely to have children follow them. Also affecting transmission is the level of conflict between parents and children. Moreover, we have seen that parents who are perceiving as open and accepting of their child's religious choices are more likely to achieve transmission. Particularly important, according to our data, is the role of a father's presence. Parental piety - religious role modeling, setting a good example - will not compensate for a distant dad. (bl. 193-195)

Intergenerasionele solidariteit en momentum in gesinne voorsien dus belangrike sleutels vir enige persone in jeugbediening wat werk met intergenerasionele geloofsvorming.

Daar is egter baie kragte in die kultuur en gemeentes aan die werk om hierdie solidariteit en momentum tussen generasies teen te werk. Hierdie kragte wat diskontinuïteit of vervreemding veroorsaak, gaan nie in hierdie artikel volledig bespreek word nie. Daar gaan slegs daarna verwys word wanneer dit op die gesin betrekking het.

Die dinamika waardeur die intergenerasionele diskontinuiteit plaasvind, word volgens Seibel (2009:37) dikwels duideliker binne die kleiner eenhede van groepe ('small world settings') soos gesinne en gemeentes, binne 'n groter samelewing raakgesien. Hierdie dinamika gaan dikwels gepaard met 'n afname van interaksie - 'n afname in gedeelde sentiment en waardes van die verskillende generasies. Die gevolg van die afsny van kommunikasie beroof, volgens Seibel (2009:54), beide ouer en jonger lede van 'n gemeenskap (ons kan hier byvoeg ouers en kinders binne gesinne) die geleentheid om gemeenskaplikheid te ontdek en te versterk, wat later kan help om die verskille te oorbrug wat op grond van ouderdomsverskille bestaan.

Dit is dus duidelik dat daar 'n natuurlike proses van diskontinuïteit tussen generasies plaasvind, wat kan lei tot isolasie indien dit nie aktief hanteer word nie. Hierdie kragte van diskontinuiteit word dikwels in gesinne op 'n natuurlike manier teengewerk, as gevolg van langtermyn-verhoudings. Wanneer hierdie proses van diskondinuiteit egter by die gemeente in en deur jeugbediening geformaliseer word, en generasies nie gehelp word met intergenerasionele solidariteit en momentum nie, kan dit bydra tot vervreemding in die huis en in die gemeente. In die lig van wat oor die uitkomste van intergenerasionele geloofsvorming gesê is, dra diskontinuiteit en die gevolglike isolasie direk daartoe by dat oriëntasie en identifikasie gebrekkig plaasvind en dat daar daarom ook nie tot ' $n$ belydenis gekom kan word nie. As diskontinuïteit nie positief hanteer word nie, lei dit uiteindelik tot vervreemding.

\section{Die rol van die ouerhuis in intergenerasionele geloofsvorming}

Binne 'n geïntegreerde jeugbediening waar die belang en noodsaakvan'nomvattendeintergenerasionelegeloofsvorming verstaan word, word vervolgens spesifiek na die rol van die ouerhuis in intergenerasionele geloofsvorming gekyk. Die ouerhuis vervul sowel 'n teologiese as 'n sosiologiese rol in intergenerasionele geloofsvorming, en is 'n belangrike sleutel in die vorming van geloof en die oordrag van 'n geloofstradisie van een generasie na die volgende. Die ouerhuis vervul die volgende belangrike funksies in die geloofsvormingsproses:

\section{Hermeneutiese funksie}

Binne die ekklesiologiese of korporatiewe ruimte is daar, volgens Nel (2018:86; cf. ook Nel 2001a:20-22; 2001b:16-17), 'n kleiner eenheid, die ouerhuis, aan wie God'n hermeneutiese funksie toegeken het, waar kinders kan leer van God en hoe Hy met mense werk. Die ouerhuis vervul 'n unieke hermeneutiese funksie in die Bybel. 'n Mens sou volgens Nel (2018:86; cf. 2001a:20) kon sê dat kinders ouers het 'om tot verstaan te kom'. Die paasmaaltyd (Ex 12) en die verwysing na gesinne en geloofsopvoeding in Deutronomium 6, is bekende voorbeelde hiervan. So leer ken 'n kind, volgens Firet (1986:53 e.v.), die 'weg van die Here met sy mense en leer verstaan dat dit ook die weg van die Here met my is'. Wanneer hierdie verhaal van God met sy mense uit die mond gehoor word van ouers (wat die kind as betroubaar ervaar), maak dit soveel meer sin. Hulle vertel aan die volgende geslag 'van die roemryke dade van die Here en van sy mag' (Ps 78:3-4). Binne die ouerhuis word God en sy handelinge, volgens Nel (2018:87), op die mees natuurlike maniere aan huisgenote geïnterpreteer en kom kinders op die mees spontane en natuurlike wyse tot verstaan. Dit is binne hierdie ruimte waar identiteitsvinding of -ontwikkeling plaasvind. 
Tog beteken dit alles nie dat God aan hierdie ruimte gebind is en dat verstaan nie kan plaasvind waar en wanneer hierdie ruimtes ontbreek of geskend is nie ( $\mathrm{Nel}$ 2018:87-88). Duisende kinders word nie binne sogenaamde tradisionele gesinne gebore nie, maar is deel van enkelouer-gesinne, of van wat Holmen (2005:9-15) gebroke en disfunksionele gesinne noem. Daar word ook baie kinders vandag gebore wat geen gesinsverbintenisse ken nie. Wanneer dié ruimte dus ontbreek, word jeugbedienings uitgedaag om verskeie goeie noodprosedures in plek te sit om so 'n veilige ruimte te voorsien waar dié begrip wel gefasiliteer kan word.

\section{Primêre geloofsvormers}

Daar is ' $n$ hele stroom internasionale en nasionale navorsing sedert die negentigerjare van die vorige eeu, wat nie net die primêre rol van ouers in geloofsvorming uitlig nie, maar ook ma's en pa's uitwys as dié persone wat die grootse invloed op die geloofsvorming van hulle kinders uitoefen (Avenant \& Hoffman 2015:64). Die sentrale bevinding van die longitudinale navorsing oor jeug en godsdiens in die VSA, is volgens Smith en Denton (2005) die volgende:

Contrary to misguided cultural stereotypes and frequent parental misperceptions, we believe that the evidence clearly shows that the single most important social influence on the religious and spiritual lives of adolescents is their parents. (bl. 261)

Ouers is die persone wat direk betrokke is by die inlywing, begeleiding en onderskeiding van hulle kinders op 'n lewenslange dissipelskapspad. Dit is belangrik om ook bogenoemde bevinding van die longitudinale navorsing, wat ook in Suid-Afrika herhaal is, waar die bevinding bevestig is, te verdiskonteer en te reflekteer in (jeug-) bediening (Avenant \& Hoffman 2015:64). Freudenburg en Lawrence (1998) doen presies dit en gebruik hierdie bevinding van die VSA as agtergrond vir hulle werksformule wat hulle soos volg beskryf:

Parents are the primary Christian educators in the church, and the family is the God-ordained institution for faith-building in children and youth and for the passing of faith from one generation to the next. (bl. 21)

Volgens Freudenburg en Lawrence is ouers primêr verantwoordelik vir die begeleiding van hulle kinders se geloofsvorming en behoort gemeentes (jeugbediening) hulle in hierdie taak te ondersteun. Freudenburg en Lawrence (1998) gaan nog een stappie verder wanneer hulle aandui tot watter besef hulle gekom het in hierdie verband:

Parents are the key faith developers for their children - they can either have a positive or a negative impact on their kids' faith growth. But either way, they'll have the biggest impact. You can have strong faith-shaping programs for kids at church, but if you're not partnering with homes, you risk producing kids who have weak faith. (bl. 77)

'n Familiegebaseerde jeugbediening behoort volgens De Vries (2004:176), die basis te wees wat elke jeugbediening nodig het om 'n langtermynimpak te hê.

\section{Geloofsvoorbeelde}

Die ouerhuis is die ruimte wat die heel beste geposisioneer is vir die impak van modellering, want almal in 'n huis (gesin of familie) leef saam in 'n langtermynverhouding, en is naby mekaar soos dit bevestig word uit die sosiale leerteorie (Nel 2018:258-259). Dit behoort dus die impak van modellering te verhoog.

Wuthnow (1999) het spesifiek die rol wat die gesin waarin iemand grootgeword het, bestudeer. Hy bevestig dat geloofsosialisering die heel beste in en deur die gesin plaasvind, waar geloofsgewoontes gereeld beoefen word. Sy navorsing lê baie klem op die karakter van die ouers se voorbeeld en die gesamentlike beoefening van geloofsgewoontes. Wuthnow (1999) vat dit bondig saam:

The daily round of family activities must somehow be brought into the presence of God. Parents praying, families eating together, conversations focusing on what is proper and improper, and sacred artifacts are all important ways in which family space is sacralized. They come together, forming an almost imperceptible mirage of experience. (bl. 8)

Hierdie saamleef in die geloof vorm nie net kinders se geloof nie, maar ook dié van die ouers. Dit is daarom uiters noodsaaklik dat ouers opgelei sal word om 'n positiewe rol en invloed ten opsigte van geloofsvorming te vervul, maar ook dit wat in hulle geloofsvoorbleed deurslaggewend is. Die ouers se konstante voorbeeld in die huis en as deelnemende lidmate van die gemeente vervul 'n onontbeerlike rol in hierdie verband. Geloofsosialisering vind beter plaas wanneer ouers in 'n lewende verhouding met Jesus Christus lewe. 'n Geloofsvoorbeeld help kinders nie net om te sien hoe geloof in die praktiese lewe werk nie, maar ook watter rol God en 'n verhouding met Hom in hulle ouers se lewe vervul.

\section{Natuurlike differensieerders}

Wat ouers en die gesin so belangrik maak binne die ruimte van intergenerasionele geloofsvorming, is die feit dat ouers en kinders uit verskillende generasies kom. Van al die persone wat betrokke is by jeugbediening, is ouers, volgens Nel (2018:262), die beste geposisioneer om op 'n natuurlike manier met hul kinders, uit 'n ander generasie, te kommunikeer. Nel noem hierdie vermoë differensiasie en beskryf dit soos volg: 'Differentiation is about discerning how to deal with a group consisting of people of different ages'. Hierdie vaardigheid om te kan differensieer, maak volgens Nel (2018:263) nie net van ouers unieke medewerkers in jeugbediening nie, maar dit skuif die mees basiese deel van jeugbediening na die ouerhuis toe. Die vermoë van differensiasie hou verder ook groot voordele in vir die meer georganiseerde vorms van jeugbediening. Ouers is daarom die ideale leiers van intergenerasionele groepe. In elke deel van jeugbediening waar die geïntegreede geheel ernstig opgeneem word, behoort ouers dus 'n sentrale rol te vervul. 


\section{Verhoudingsbouers}

Die rol en invloed wat die gesinsverhouding en atmosfeer in die huis vervul, mag nie onderskat word in intergenerasionele geloofsvorming nie. Dit is so maklik, volgens Roehlkepartian (2016:13), om die skynbaar doodgewone van elke dag se dinamika van die gesinslewe oor te sien as 'n belangrike sleutel in geloofsvorming. Die kwaliteit van die ouerkindverhoudings gedurende die vormingsjare, is volgens Roehlkepartian (2016:14) dalk een van die beste voorspellers daarvan of geloofsoortuigings en die waardes van ouers deur hulle kinders omarm gaan word, of nie.

\section{Die nie-nakoming van hierdie funksies}

Die vraag oor die rol van ouers in geloofsvorming in belang van 'n geïntegreerde jeugbediening, kan nie net gesystap word deur argumente dat hulle nie hulle verantwoordelikheid nakom nie. Hulle het steeds die grootste invloed op hulle kinders se geloofsvorming. Die invloed is dan net negatief. Smith en Snell (2009) druk dit in sosiologiese taal nog duideliker uit:

The question is never whether adults are engaged in religious socialization, but only how and with what effect they are doing so. (bl. 286)

Indien hulle nie toegewyd lewe nie, beteken dit dus hulle invloed gaan negatief wees op hullekinders se geloofsvorming, en hulle betrokkenheid by die gemeente. Jeugbedienings en gemeentes behoort maniere te vind hoe om ouers te begelei in húlle geloofsvorming en -groei. Miskien is die ouerhuis en ouers juis die plek waar jeugbedienings en gemeentes kan begin wanneer daar enigsins erns gemaak wil word met geloofsvorming en die oordra van'n positiewe geloofstradisie.

\section{Voorstelle om die ouerhuis deel te maak van 'n geïntegreerde jeugbediening}

Wanneer Cannister (2013:203 e.v.) die belang van die ouerhuis besef, argumenteer hy dat jeugbedienings met ouers in vennootskap moet gaan, en ouers toerus vir hulle geloofsvormingstaak. Hoe kan jeugbediening en gemeentes egter vennote wees van gesinne in die vorming van geloof, binne 'n komplekse en veranderende wêreld? Die uitdaging vir gemeentes begin, volgens Roehlkepartian (2016:16-24), wanneer die gemeente se gevormde narratiewe verander oor die benadering van en betrokkenheid by gesinne. Hy stel ses skuiwe voor, wat die potensiaal het om die narratiewe waarmee daar tans in gemeentes gewerk word, ten opsigte van geloofsvorming radikaal te verander. Die ses skuiwe wat hy voorstel, is die volgende: (1) verskuif van 'n klem op strategieë en programme wat 'verkoop' moet word om ouers betrokke te kry, na 'n klem op verhoudings, waar vertroue gebou, geluister word en aangesluit word by waar hulle is; (2) verskuif van 'n klem op ouerskap as 'n strategie om kinders te beïnvloed en te beheer, na 'n klem op ouerskap as 'n verhouding wat die klem plaas op teenwoordig wees en gemeenskaplikheid; (3) verskuif van 'n klem op etikettering, wat fokus op wat verkeerd is, of idealisering, wat fokus op hoe die gesin behoort te wees, na 'n klem op die benutting van gesinne se sterk punte en veerkragtigheid; (4) verskuif van klem op oordrag (passing-on) van oortuigings, na 'n klem op geloof as 'n verhouding waarin geleef word (living-into); (5) verskuif van klem om gesinne te dien (doen iets vir hulle), na 'n klem op die bemagtiging om hulle geloof uit te leef; en (6) verskuif van klem op die uitleef van geloof by die gemeente, na klem op die uitleef van geloof in hulle daaglikse lewe waar hulle is.

\section{Empiriese data vanuit gemeentes met 'n gesins- en/of familie- en/of intergenerasionele fokus in hulle (jeug-) bediening}

Kwantitatiewe navorsing met betrekking tot intergenerasionele geloofsvorming is onder 175 ouers wat uit gemeentes in die Noordelike, Oostelike, Hoëveld- en Goudlandse sinodes van die Nederduitse Gereformeerde Kerk kom, is in November 2019 gedoen. Hierdie ouers is met 'n doelgerigte steekproefmetode (purposive sample) as deel van 'n niewaarskynlikheid-steekproefmetode (non-probability sample technique) geïdentifiseer (Etikan \& Bala 2017,149-151). Die ouers kom almal uit 29 van die 436 gemeentes in bogenoemde 4 sinodale streke. Hierdie 29 gemeentes het almal 'n gesins- en/of familie- en/of intergenerasionele fokus in hulle (jeug-) bediening. Hierdie kwantitatiewe navorsing is opgevolg deur kwalitatiewe navorsing, wat tussen 25 Februarie en 05 Maart 2020 gedoen is by 10 van die leraars, wat op 'n ewekansige manier uit die 29 deelnemende gemeentes geïdentifiseer is. Die ewekansigheid het ook die geografiese gegewenheid verdiskonteer.

Die doel van hierdie empiriese studie was om te verstaan hoe die praxis van intergenerasionele geloofsvorming tans binne die jeugbediening van gemeentes met 'n gesins- en/of familie en/of intergenerasionele geloofsvorming werk, en hoe die ouerhuis daarin 'n rol speel.

In die kwantitatiewe navorsing is duidelik gesien dat die respondente (ouers) nie meer oortuig hoef te word van hulle rol as die primêre geloofsvormers nie, maar eerder begelei moet word oor hoe hulle dit kan doen. Altesaam 99\% van die respondente het aangedui dat hulle besef die huis (gesin of familie) is die primêre plek waar kinders se geloof gevorm word. ' $n$ Hele $74 \%$ wil graag daarby betrokke wees, maar weet nie hoe nie. Hierdie data help om te verstaan dat ouers ondersteuning en leiding nodig het.

Daar kan ook duidelik uit die data van die respondente in die kwantitatiewe navorsing gesien word dat ouers 'n groter bydrae lewer tot geloofsvorming, as enige ander persoon, faktor of praktyk in die gemeente. Altesaam 98\% van die respondente (ouers), dui aan dat die ma's se geloof, en $90 \%$ dat die pa's se geloof, die grootste invloed op hulle en hulle gesin se geloofsvorming het. Daarenteen dui 63\% aan dat kategete, en $54 \%$ dat die dominee by die kerk die grootste invloed op hulle kinders en gesin se geloofsvorming het. Hierdie data bevestig nie net die invloed van ouers in geloofsvorming nie, maar help ons ook verstaan dat jeugbedienings baie moeite behoort te doen om ouers te 
begelei, om sterk geloofsverhoudings te ontwikkel. Dit bevestig ook die feit dat jeugbedienings ouers behoort te betrek indien hulle enigsins 'n rol wil speel in geloofsvorming.

Wanneer die veranderlikes in die kwantitatiewe navorsing bestudeer word, wys dit dat daar beslis 'n direkte verband is tussen die beoefening van geloofsgewoontes in die respondente se huise, en dié van hulle huise van herkoms. Die verbande wat uitgewys is, is spesifiek ten opsige van Bybellees, gebed, die deel van geloofstories, dienslewering as gesin saam buite die gesin, en om 'n geloofsperspektief oor die reëls van die huis te deel. Die data het ook baie duidelik uitgewys dat die afwesigheid van die voorbeeld van ouers ten opsigte van geloofsgewoontes net so groot is en bydra tot die losmaking of ontkoppeling van enige geloofstradisies. Dit laat jeugbedienaars besef dat ouerhuise begelei behoort te word in die ontwikkeling, kweking en beoefening van geloofsgewoontes.

Dit is opvallend dat warm liefdevolle verhoudings in die huis (96\%), en warm liefdevolle en 'n verwelkomende gesindheid van die gemeentes $(77 \%)$ baie belangrik geag word as bydraende faktore in geloofsvorming. In beide gevalle was dit as dié belangrikste bydraende faktor in geloofsvorming in die huis en gemeente, uitgewys. Dit beteken dat jeugbedienings baie moeite behoort te doen in die skep van warm liefdevolle en verwelkomende omgewings, waarbinne die bediening plaasvind, maar ouerhuise behoort ook toegerus te word sodat warm liefdevolle verhoudings in die ouerhuis kan ontwikkel.

Daar is egter een stukkie kommerwekkende inligting uit die kwantitatiewe navorsing, oor die ervaring in die ouerhuis, waarvan deeglik kennis geneem behoort te word: toerusting word nie deur ouers beskou as iets wat 'n groot bydrae tot die geloofsvorming van hulle kinders en gesin kan lewer nie. Slegs $22 \%$ het aangedui dat dit 'n positiewe effek op geloofsvorming in hulle huis (gesin of familie) het. Daar is dus wel 'n behoefte aan toerusting aan die een kant, maar wat en hoe dit tans beskou word, dra nie by tot positiewe geloofsvorming in die gesin nie. Daar sal dus beslis nuut en kreatief oor opleiding en toerusting van ouerhuise in die toekoms gedink moet word.

In die kwalitatiewe navorsing, was dit opvallend dat byna alle respondente (leraars) aangedui het dat hulle gesinsen/of familie- en/of intergenerasionele fokus voortspruit of die gevolg is van een of ander paradigmaskuif wat hulle gemeentes of jeugbedienings gemaak het. Die paradigmaskuiwe behels een van, of ' $n$ kombinasie van die volgende: Ouers is die primêre geloofsvormers, die huis en die kerk is vennote, gesinne moet gë̈ntegreerd bedien word, intergenerasionele bediening is belangrik, en onderrig gaan oor geloofsvorming en nie net oor kennisoordrag nie. Hierdie data help jeugbedienings om te weet waar hulle kan begin wanneer hulle die ouerhuis die kerndeel van hulle jeugbediening wil maak.
In die kwalitatiewe en kwantitatiewe navorsing is gevra na die faktore wat 'n positiewe effek op die vorming en groei van geloof in gesinne het. Die volgende faktore is in die kwalitatiewe navorsing deur die respondente (leraars) uitgewys: In byna al die voorstedelike gemeentes is ' $n$ duidelike gedefinieerde, geïntegreerde en gekoördineerde bedieningsplan vir geloofsvorming uitgewys. Hierdie plan behels ' $n$ gedeelde visie, wat bestaan uit die instem tot en voorleef van die visie vir geloofsvorming deur die leierskap, kategete en ouers. Dit is vanuit hierdie visie en geleefde geloof dat die leierskap, kategete en ouers 'n mentorsrol inneem. Dit behels verder ' $n$ eenvormige geloofsvormingsproses by die huis en in die gemeente. Dit vra natuurlik ook die instemming van die ouers en die leierskap. Laastens behels die plan dat almal in die drie kernbedieninge wat uitgewys is (Erediens, kategese en huisgeloof), dieselfde ritmes (teks of tema vir alle ouderdomme) volg. In die kwantitatiewe navorsing is kategese/Sondagskool/belydenisklas (73\%) en die erediens (71\%) onderskeidelik as die tweede en derde belangrikste faktore uitgewys, wat na die respondente (ouers) se mening die grootste positiewe effek op die vorming en groei van hulle gesinne of families se geloof het. Die warm, liefdevolle en verwelkomende gesindheid in hul gemeente $(77 \%)$, is in die kwantitatiewe navorsing deur respondente (ouers) as die belangrikste faktor uitgewys, wat die grootste positiewe effek op die vorming en groei van hulle gesinne of families se geloof het. In die kwalitatiewe navorsing het slegs die plattelandse respondente (leraars) direk verwys na verhoudings en atmosfeer as bydraende faktore wat die grootste effek in die vorming en groei van geloof in gesinne of families het. Hierdie data help jeugbedienings om te weet wat prakties gedoen kan word om die ouerhuis 'n kerndeel van die jeugbediening te maak.

Die grootste knelpunt wat in die empiriese navorsing uitgewys is, is reeds hanteer, naamlik die kapasiteit van ouers ten opsigte van geloofsvorming wat onder geweldige druk is. In die kwantitatiewe navorsing het meer as tweederdes (69\%) van die respondente (ouers) aangedui dat hulle grootste uitdaging in hulle geloofsvormingstaak is, om tyd te vind as familie saam. In die kwalitatiewe navorsing het byna al die respondente die kapasiteit van ouers uitgewys as die grootste uitdaging vir intergenerasionele geloofsvorming. Dit is tog verblydend dat die meerderheid van die respondente wat aan die kwantitatiewe navorsing deelgeneem het, maniere gevind het om uit te kom by dit wat vir hulle belangrik is. Hierdie uitdaging sal toenemend in jeugbediening verdiskonteer moet word. Op grond van wat in die literatuur uitgewys is, asook al die bovermelde data, sal dit onverantwoordelik wees om die ouerhuis se rol in intergenerasionele geloofsvorming te ontken. Dit sal verder ook onverantwoordelik wees om ouers nie by 'n geïntegreerde, inklusiewe jeugbediening te betrek nie.

\section{Gevolgtrekkings en slotopmerkings}

In hierdie artikel is geargumenteer dat die ouerhuis 'n deurslaggewende rol in dieintergenerasionele geloofsvorming van die jeug in belang van ' $n$ geïntegreerde jeugbediening 
vervul. Hierdie invloed kan egter positief of negatief wees. Jeugbedienings behoort daarom seker te maak dat ouers in die kern van hulle bediening staan sodat ouers begelei, ondersteun en bemagtig kan word om eerstens self te groei in hulle toewyding en om dan as geloofsvoorbeelde 'n positiewe invloed op hulle kinders se geloof te kan hê.

In hierdie navorsing is uitgewys dat ouers 'n onontbeerlike rol in die geloofsvormingsproses van hulle kinders vervul. Hulle is nie net primêre geloofsbemiddelaars nie, maar ook aktief betrokke by die vorming van hulle kinders se geloof. Binne hulle kinders se identiteitsvinding begelei ouers hulle kinders in hul oriëntasie en identifikasie om uiteindelik by 'n belydenis te kom. Hierdie teologiese funksie van die ouerhuis word ook aangevul deur hulle sosiologiese funksie om as geloofsvoorbeelde en verhoudingsbouers by te dra tot die skep van 'n ruimte waarbinne hulle kinders se geloof kan ontwikkel en groei. Wanneer 'n geïntegreerde jeugbediening egter ontbreek, en die ouerhuis losgemaak word van die belangrike rol en funksie wat dit het, vind daar intergenerasionele diskontinuïteit plaas, wat oriëntasie, identifikasie en uiteindelik 'n persoonlike belydenis baie moeilik maak. Jeugbedienings kan op geen manier die rol wat ouers in kinders se lewens vervul met programme, strukture en selfs verhoudings vervang nie. Wanneer die ouerhuis en jeugbedienings nie as vennote in die geloofsvormingsproses optree nie, lei dit nie net tot swak geloof nie, maar ook tot onverbondenheid, onvolhoubaarheid en uiteindelik vervreemding. Hierdie toedrag van sake beklemtoon die feit dat ouers en jeugbedienings mekaar nodig het, en daarom 'n onmisbare vennootskap behoort te sluit. Jeugbedienings kan nie sonder 'n geïntegreerde bediening, wat die jeug en pertinent die ouerhuis insluit, effektief funksioneer nie. Vir effektiewe oordrag van geloof van een generasie na die volgende, asook vir volhoubare kerkwees, is hierdie vennootskap onontbeerlik. Die ouerhuis kan ook nie vandag, met al die uitdagings wat die huis se kapasiteit bedreig, sonder inklusiewe jeugbediening effektief funksioneer nie.

Die navorsing het dus duidelik uitgewys dat $\mathrm{Nel}$ se teorie van inklusiewe jeugbediening, nie net waardevol is om van kennis te neem nie, maar ook noodsaaklik is om op die langtermyn te kan meewerk aan die gemeente se eskatologiese volhoubaarheid.

\section{Erkennings \\ Mededingende belange}

Die skrywers verklaar dat hulle geen finansiële of persoonlike verbintenis het met enige party wat hulle nadelig kon beïnloed het in die skryf van hierdie artikel nie.

\section{Outeursbydraes}

J.C.A. was verantwoordelik vir die konseptualisering, keuse van metodologie, navorsing, ontledings, opteken van statistiek, projekadministrasie, keuse van bronne en die skryf van die artikel. M.N. was verantwoordelik vir aanvanklike konseptualisering, keuse van metodologie, visualisering van en toesighouding oor die projek. J.J. was verantwoordelik vir die keuse van die navorsingsmetode en statistiese verwerkings van die kwantitatiewe navorsing.

\section{Etiese oorwegings}

Hierdie studie is uitgevoer met die toestemming van die navorsingskommittee aan die Fakulteit Teologie.

\section{Befondsing}

Hierdie projek is finansieel deur die Suid-Afrikaanse Akademie vir Wetenskap en Kuns ondersteun.

\section{Databeskikbaarheid}

Daar is geen beperkings op die data wat in hierdie artikel verskaf word nie.

\section{Vrywaring}

Die sienings en menings wat in hierdie artikel uitgedruk word, is dié van die skrywers en weerspieël nie noodwendig die amptelike beleid of posisie van enige geaffilieerde agentskap van die skrywers nie.

\section{Literatuurverwysings}

Allen, H.C. \& Ross, C.L., 2012, Intergenerational Christian formation: Bringing the whole church together in ministry, community and worship, InterVarsity, Downers Grove, IL.

Avenant, J.C. \& Hoffman, L., 2015, 'Geloofsvorming', in M. Nel \& Z. van der Westhuizen (reds.), Skokkend positief: Insigte vanuit nuwe navorsing oor aktiewe Afrikaanse kerkjeug, pp.63-74, Bibel_Media, Wellington.

Bengston, V., Putney, N.M. \& Harris, S., 2013, Families and faith: How religion is passed down across generations, Oxford University Press, New York, NY.

Bijlsma, R., 1962, Kleine catechetiek, Callenbach, Nijkerk.

Bosch, D.J., 1979, Heil vir die wêreld, NGKB, Pretoria.

Bosch, D.J., 1991, Transforming mission, Orbis, Mary Knoll, NY.

Brierley, P., 1993, Reaching and keeping teenagers, MARC, Tunbridge Wells.

Cannister, M.W., 2013, Teenagers matter: Making student ministry a priority in the church, Baker Academic, Grand Rapids, MI. (Youth, Family, and Culture Series).

Corbett, J.M. \& Johnson, C.E., 1972, It's happening with youth, Harper \& Row, New York, NY.

De Vries, M., 2004, Family-based youth, 2nd edn., InterVarsity, Downers Grove, IL.

Dingemans, G.D.J., 1986, In de leerschool van het geloof: Mathetiek en vakdidactiek voor katechese en kerkelijk vormingswerk, Kok, Kampen.

Etikan, I. \& Bala, K., 2017, 'Sampling and sampling methods', Biometrics \& Biostatistics International Journal 5(6):00149-00151, viewed 09 July 2020, from https:// d1wqtxts1xzle7.cloudfront.net/56588350/sampling_methods.pdf? $1526549596=$ \&response-content.

Firet, J., 1977, Het agogisch moment in het pastoraal optreden, 3de druk, Kok, Kampen.

Firet, J., 1982, Het agogisch moment in het pastoraal optreden, 4de druk, JH Kok, Kampen.

Firet, J., 1986, Dynamics in pastoring, Eerdmans, Grand Rapids, MI.

Freudenburg, B. \& Lawrence, R., 1998, Family friendly church, Group Publishing, Loveland, CO.

Harris, M., 1989, Fashion me a people: Curriculum in the church, John Knox Press, Louisville, KY

Holmen, M., 2005, Faith begins at home, Regal, Ventura, CA.

Holmen, M.A., 2010, Church+Home - The proven formula for building lifelong faith, Regal Books, Ventura, CA.

Kreider, A., 1999, The change of conversion and the origin of Christendom, Wipf \& Stock, Eugene, OR.

Nederduitse Gereformeerde Kerk (NGK), Algemene Sinode, 2019, Agenda - 2019 Geloofsvorming: Jeug, Sub-Taakspan belydenis van geloof, bl. 288-302, besigtig: 12 January 2020, vanaf https://www.kerkargief.co.za/doks/acta/AS_Agenda_ 2019.pdf 
Nel, M., 1994, Gemeentebou, Orion Uitgewers, Halfway House.

Nel, M., 2001a, Jeugbediening - 'n Inklusiewe gemeentelike benadering, Barnabas, Bloemfontein.

Nel, M., 2001b, 'The inclusive congregational approach to youth ministry (2-22)', in M.H. Senter, W. Black, C. Clark \& M. Nel (eds.), Four views of youth ministry and the church: Inclusive congregational preparatory, missional, strategic, Zondervan/ Youth Specialties, Grand Rapids, MI.

Nel, M., 2009, 'Imagine-making disciples in youth ministry that will make disciples', HTS Teologiese Studies/Theological Studies 71(3), 1-11. https://doi.org/10.4102/ hts.v71i3.2940

Nel, M., 2015, Identity-driven churches - Who are we, and where are we going? Biblecor, Bible Media, Wellington.

$\mathrm{Nel}, \mathrm{M} ., 2018$, Youth ministry: An inclusive missional approach, AOSIS, Cape Town. (HTS Religion \& Society Series: 1). https://doi.org/10.4102/aosis.2018. BK83.05

Nel, M. \& Van der Westhuizen, Z., 2015, Skokkend positief: Insigte vanuit nuwe navorsing oor aktiewe Afrikaanse kerkjeug, Bybel-Media, Wellington.

Neufeld, T., 2002, 'Postmodern models of youth ministry', Direction 31(2), 194-205, besigtig 04 July 2019, vanaf https://directionjournal.org/31/2/postmodernmodels-of-youth-ministry.html

Osmer, R.R., 1996, Confirmation: Presbyterian practices in ecumenical perspective, Geneva Press, Louisville, KY.

Osmer, R.R., 2008, Practical theology. An introduction, Eerdmans, Grand Rapids, MI.

Prins, R., 1995, 'Die vernuwing van die kategese in die NG Kerk: Die sprong van teorie na praktyk', NG Teologiese Tydskrif 36(1), 24-35.
Roberto, J., 2016, 'Understanding twenty-first century parents and families: A review of research trends', in L. Kehrwald, J. Roberto, G. Roehlkepartian \& J. Roehlkepartian (eds.), Families at the centre of faith formation, bl. 27-52, Lifelong Faith Associates, Naugatuck, CT.

Roehlkepartain, G., 2016, 'Transforming narratives of families for the twenty-first century', in L. Kehrwald J. Roberto G. Roehlkepartian \& J. Roehlkepartian (eds.), Families at the centre of faith formation, pp. 7-24, Lifelong Faith Associates, Naugatuck, CT.

Seibel, C., 2009, 'Intergenerational reconciliation and justice as essential dimensions of missional renewal in the postmodern transition', Unpublished PhD thesis, University of Pretoria.

Simpson, N.W., 1999, 'Traditioning and reinterpretation: The quest for a methodology for faith-formation', PhD thesis, University of Stellenbosch.

Smith, C. \& Denton, M.L., 2005, Soul searching: The religious and spiritual lives of American teenagers, Oxford University Press, New York, NY.

Smith, C. \& Snell, P., 2009, Souls in transition: Religious \& spiritual lives of emerging adults, Oxford University Press, New York, NY.

Wepener, C., 2014, Van voor die wieg tot na die graf: Rituele roetemerkers vir die drumpels van die lewe, BybelMedia, Wellington.

Westerhoff, J.H., 2000, Will our children have faith, 2nd rev. edn., Morehouse, Toronto.

White, J.R., 1988, Intergenerational religious education: Models, theory, and prescription for interage life and learning in the faith community, Religious Education Press, Mishawaka, IN.

Wilhoit, J.C., 2008, Spiritual formationals if the church mattered: Growing in Christ through community, Baker Academic, Grand Rapids, MI.

Wuthnow, R., 1999, Growing up religious: Christians and Jews and their journeys of faith, Beacon Press, Boston, MA. 